\title{
33. OXIC VS. ANOXIC DIAGENETIC ALTERATION OF TURBIDITIC SEDIMENTS IN THE MADEIRA ABYSSAL PLAIN, EASTERN NORTH ATLANTIC ${ }^{1}$
}

\author{
Gert J. De Lange ${ }^{2}$
}

\begin{abstract}
Upon deposition, downward diffusing oxygen results in the "burn-down" of the upper part of organic-rich turbidites in the Madeira Abyssal Plain. This oxidation front is terminated after a few thousand years, on average, at the moment of deposition of the next turbidite. These initially homogeneous sediments form an excellent setting for studying long-term organic matter remineralization processes to establish the extent and possible selectivity of oxic vs. anoxic degradation of organic matter in a natural environment. Samples for this study have been taken from the oxidized upper part and the unoxidized lower part (from 42 to 280 meters below seafloor) of 13 organic-rich turbidites 1.2-14 m.y. old. The organic fraction in the lower part of organicrich turbidites has remained virtually unchanged for periods as long as $14 \mathrm{~m} . \mathrm{y}$. under suboxic to anoxic conditions. In contrast, dramatic changes have occurred during the post-depositional oxidation of sediments in the tops of the same turbidites by oxygen. This has resulted in a large decrease in the organic carbon $(-80 \%)$ and total nitrogen content $(-50 \%)$ of the upper, relative to the lower, parts of these turbidites. In addition, this oxidation process has resulted in a ${ }^{13} \mathrm{C}_{\mathrm{org}}$ that is, on average, $1.5 \% \%$ more negative and a ${ }^{15} \mathrm{~N}_{\text {tot }}$ that is $1.3 \%$ more positive in the upper oxidized samples than it is in the lower unoxidized ones from within the same turbidite. The seemingly selective preservation of organic matter that is low in $\mathrm{C} / \mathrm{N}$ and has a relatively negative ${ }^{13} \mathrm{C}_{\text {org }}$ is usually interpreted as being indicative of better preservation of terrestrial organic matter relative to marine organic matter. However, it could equally be explained by the different preservation of certain marine compounds with, on average, distinctly different ${ }^{13} \mathrm{C}_{\text {org }}$ and $\mathrm{C} / \mathrm{N}$ ratios. Furthermore, a decrease is observed in the total carbonate content, which is related in part to the oxidation of organic matter and S-compounds. For some samples, however, it may also be related to a more shallow carbonate compensation depth and/or some bioturbation during the downward oxidation process. Major and minor element compositions of sediments do not seem to be affected by the oxidation process if they are normalized to Al. Sulfur is the main exception. Upon oxidation, the reduced (mostly pyrite) S-compounds produce acid and sulfate, which dissolves carbonate and diffuses away in the pore water, respectively.
\end{abstract}

\section{INTRODUCTION}

Madeira Abyssal Plain (MAP) sediments deposited during the last 10 m.y. consist predominantly of meter-thick turbidites interbedded with thin layers of pelagic sediment (Weaver and Kuijpers, 1983; Kuijpers and Weaver, 1985; Weaver and Rothwell, 1987; Weaver et al., 1992; Schmincke, Weaver, Firth, et al., 1995; Rothwell et al., Chap. 28, this volume; Weaver et al., Chap. 38, this volume). The chemical composition of the turbiditic sediments is determined mainly by their provenance. On the basis of geochemical data, three distinct groups of turbidites have been recognized (e.g., De Lange et al., 1987): (1) organic-rich turbidites, (2) turbidites with a volcanic component, and (3) carbonate-rich turbidites. The composition within the carbonate-rich and "volcanic" turbidites is rather homogeneous, whereas that within the organic-rich turbidites is more complex because of post-depositional oxidation of the top part of these turbidites.

After emplacement, the tops of the organic-rich turbidites have been oxidized by oxygen diffusing into the sediment from the overlying sea water (Colley et al., 1984; Colley and Thomson, 1985; Thomson et al., 1984; Wilson et al., 1985, 1986; Thomson et al., 1987; De Lange et al., 1987; Van Os et al., 1993; Thomson et al., 1993). Consequently, the $\mathrm{C}_{\text {org }}$ content of the upper portions of some turbidites has been decreased to very low levels (Jarvis and Higgs, 1987; De Lange et al., 1987; Prahl et al., 1989; De Lange, 1990; Cowie et al., 1995).

${ }^{1}$ Weaver, P.P.E., Schmincke, H.-U., Firth, J.V., and Duffield, W. (Eds.), 1998. Proc. ODP, Sci. Results, 157: College Station, TX (Ocean Drilling Program).

${ }^{2}$ Utrecht University, Institute of Earth Sciences, Department of Geochemistry, Budapestlaan 4, 3584 CD Utrecht, The Netherlands. gdlange@earth.ruu.nl
On the basis of pore-water and sediment results from the upper 35 $\mathrm{m}$ of sediment, it was concluded that the organic matter that is presently decomposing under sulfate-reducing conditions (below $35 \mathrm{~m}$ ) is similar to that decomposed under oxygenated conditions in the upper $35 \mathrm{~m}$ (De Lange, 1990, 1992a). In addition, it was shown that the decomposition rate of organic matter under oxygenated conditions is orders of magnitude higher than it is under reducing conditions. However, despite the $>80 \%$ reduction in organic matter content, there is no change in the relative values of some organic geochemical paleotemperature indicators (Prahl et al., 1989; De Lange et al., 1994; Cowie et al., 1995). In contrast, the ${ }^{13} \mathrm{C}_{\text {org }}$ and ${ }^{15} \mathrm{~N}_{\text {tot }}$ appear to change considerably (De Lange et al., 1994; Prahl et al., 1997) and pollen disappear almost entirely (Keil et al., 1994; K. Zonneveld, pers. comm., 1997). As the initial sediment composition was homogeneous for each of the fine-grained organic-rich tubidites of the MAP, the observed changes can only be caused by the availability of dissolved oxygen. It appears, therefore, that a certain class of organic matter can be degraded at relatively high rates only if oxygen is available.

All of these results have been based on data originating from the F-turbidite alone (emplacement $\sim 127 \mathrm{ka}$; Weaver and Rothwell, 1987). In the present study, it has been possible to extend not only the diversity (in composition and origin) of turbidites, but also the time interval of storage of organic matter from the late Quaternary to the middle to late Miocene.

The homogeneous organic-rich turbidites of the MAP offer a unique opportunity to study the stability under oxygenated conditions of organic matter and of sedimentary constituents that are related to organic matter. These "in situ oxidation experiments" of downward diffusing oxygen (lasting for 1 to $50 \mathrm{k} . \mathrm{y}$. in the various turbidites), therefore, form the equivalent of long-term laboratory experiments

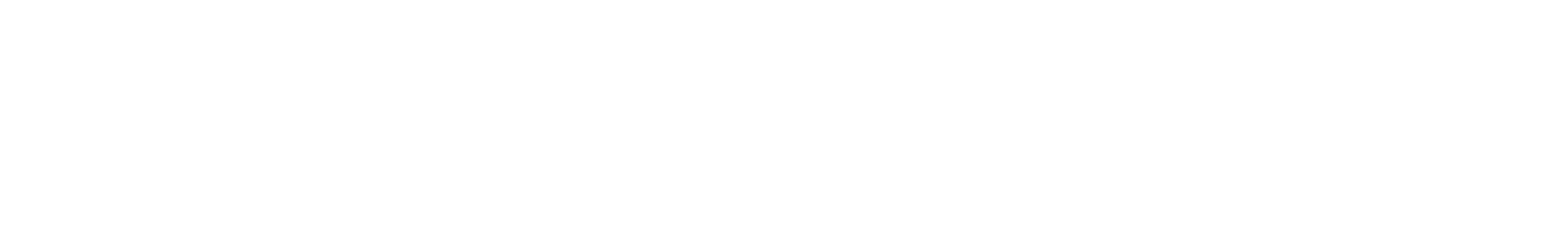


under well-controlled conditions (homogenous and well-defined composition of the sediment at the start of the "experiment") and are the ideal basis for studying long-term decomposition of organic matter and related diagenetic reactions (e.g., Jumars et al., 1988; De Lange et al., 1994). In addition, the diversity of organic-rich turbidites of the MAP offers an excellent possibility to study the impact of post-depositional oxidation on organic matter composition of different types and with different post-emplacement time spans of diagenesis. Moreover, the differences in oxic and anoxic (bio)degradation that are observed contribute significantly to the ongoing debate about the rates at which organic matter is remineralized under oxic and anoxic conditions (e.g., Canfield, 1989; Prahl et al., 1989; Pedersen and Calvert, 1990; De Lange et al., 1994).

\section{METHODS}

Samples were collected aboard the JOIDES Resolution in geochemical bags and were stored and transported dark and frozen from the ship to the shore-based laboratory at Utrecht. Subsequently, each sample was freeze-dried, homogenized by gentle mixing, and split into identical subsamples for analysis of amino acids, carbohydrates (Cowie et al., Chap. 34, this volume), organic geochemistry/ macromolecules (Hoefs et al., Chap. 35, this volume), and $\mathrm{C}_{\text {org }}, \mathrm{N}_{\text {tot }}$, $\mathrm{CaCO}_{3},{ }^{13} \mathrm{C}_{\text {org }},{ }^{15} \mathrm{~N}_{\text {tot }}$, and inorganic composition.

The samples were then powdered, and $0.250 \mathrm{~g}$ was used for total dissolution in an acid mixture of $\mathrm{HF}, \mathrm{HClO}_{4}, \mathrm{HNO}_{3}$ (De Lange et al., 1987), which, after dry evaporation, was dissolved in $50 \mathrm{ml}$ of $1 \mathrm{~N}$ $\mathrm{HCl}$ solution. Concentrations of major and minor elements were determined using an ICP-AES Optima 3000. Standard deviations of the major elements were better than $4 \%$; most of the minor elements were better than $8 \%$.

$\mathrm{C}_{\text {org }}, \mathrm{N}_{\text {tot }}$, and ${ }^{15} \mathrm{~N}_{\text {tot }}$ were determined on decarbonated samples (twice in a $1 \mathrm{~N} \mathrm{HCl}$ solution [Van Santvoort et al., 1996]) and in untreated samples $\left(\mathrm{C}_{\text {org }}\right)$, using a Carlo Erba NA1500 CNS analyzer and a con-flo 2 interface coupled Finnigan delta $S$ mass spectrometer, with dry combustion at $1800^{\circ} \mathrm{C}$. Reported ${ }^{15} \mathrm{~N}_{\text {tot }}$ values have a precision better than $0.2 \%$ o for unoxidized samples, but lower and variable precision for oxidized samples. The percent $\mathrm{CaCO}_{3}$ was obtained by subtracting the percent $\mathrm{C}$ in untreated samples from that in decarbonated samples; ${ }^{13} \mathrm{C}_{\text {org }}$ was measured on decarbonated samples using a VG SIRA mass spectrometer with a precision better than $0.1 \%$ (Van Os et al., 1996).

\section{RESULTS AND DISCUSSION}

The initial organic matter composition above and below the oxidation front in organic-rich turbidites in the MAP may be considered identical. Therefore, these turbidites offer an excellent opportunity directly to recognize the impact of long-term post-depositional oxidation of organic matter. For this purpose, samples have been taken from 13 different turbidite intervals, referred to as ox/unox intervals $1-13$, over a large range of depths (Table 1), times of deposition, and redox states. Intervals $2-5$ and 8-10 are "suboxic," with a diffusioncontrolled decrease in pore-water sulfate concentration and deposition times of up to $8 \mathrm{Ma}$, whereas intervals 6-7 and 11-13 are anoxic with low (if any) sulfate and increasing methane concentrations and deposition times of up to $14 \mathrm{Ma}$. The first sample in each of the intervals $2-13$ originates from the oxidized top part of a turbidite. Conversely, the lower two to three samples per interval and the single sample from interval 1 all come from the unoxidized lower part of the same turbidite (Table 1). This configuration has been illustrated for intervals 7, 9, and 11 in Figure 1.

Each turbidite is overlain by a relatively thin pelagic interval, which, in turn, is overlain by the next turbidite. Upon deposition of the latter turbidite, the diffusion of oxygen into the surface of the former is instantaneously cut off, ending the period of a downwardmoving oxidation front. The paleo-oxidation front then remains "frozen" in the sedimentary record.

During the period of pelagic deposition, some bioturbative mixing has occurred in the upper part of the oxidized intervals. This mixing is visible in the contrasting colors of light bluish oxidized turbidite and white or brown to dark brown pelagic sediment. Most "oxidized" samples seem to have been taken from below this bioturbation zone and can be considered to consist mostly, if not entirely, of oxidized turbidite material. Sample 5007 forms a possible exception.

Although sulfate reduction seems to be active below 100 meters below seafloor (mbsf) in Holes 951 and 952, a substantial part of the decrease in pore-water sulfate concentration might be attributed to methane oxidation rather than to sulfate-mediated organic matter degradation (compare De Lange, 1992a, with Schmincke, Weaver, Firth, et al., 1995). The sediments in Hole 952, in particular, seem to be governed by this process, as is demonstrated by the linear sulfate concentration vs. depth profile and the concomitant downward increase of methane below this depth. Accordingly, post-depositional sulfate reduction may not have changed the organic composition in these sediments to any substantial degree. Consequently, a direct comparison between unoxidized lower and (paleo-) oxidized upper parts of even the deeper turbidites has not been changed by subsequent sulfate reduction.

\section{Percent $\mathrm{C}_{\text {org }}$, Percent $\mathrm{N}_{\text {tot }}$, and $\mathrm{C}_{\text {org }} / \mathrm{N}_{\text {tot }}$ Ratio}

Intervals 2-13 demonstrate the expected dramatic change in organic matter parameters (Table 1) between the unoxidized lower part and the oxidized upper part of each turbidite. The largest change in percent $\mathrm{C}_{\text {org }}$ occurs in intervals 7 and 8 , where $86 \%-87 \%$ of the initial organic $\mathrm{C}$ has been degraded. The smallest change appears to occur in interval 11 , with a $72 \%$ decrease (however, see below). In most intervals, the organic carbon has degraded by $\sim 80 \%$ of its initial value (Table 2).

The relative amount of degradation of $\mathrm{N}$ (average $=50 \%$ ) appears to be slightly less than that for carbon, resulting in a decrease upon oxidation of the $\mathrm{C}_{\text {org }} / \mathrm{N}_{\text {tot }}(\mathrm{C} / \mathrm{N})$ ratio from 11 to 13 in unoxidized samples to 4 to 5 in oxidized samples. Part of the $\mathrm{N}$ in marine sediments is "fixed" to clay and may not be readily available for degradation (e.g., Stevenson and Cheng, 1972; Müller, 1977; De Lange, 1992a). Although fixed N may compose $18 \%-96 \%$ of the total sedimentary $\mathrm{N}$ content, the quantity of $\mathrm{N}_{\text {fix }}$ for the top $35 \mathrm{~m}$ of the MAP organicrich turbiditic sediments rarely amounts to $10 \%$ of the total $\mathrm{N}$ of the unoxidized samples (De Lange, 1992a). Consequently, it seems unlikely that the shift in the $\mathrm{C} / \mathrm{N}$ ratio results from the $\mathrm{N}_{\text {fix }}$ fraction, as determined by the commonly used Silva and Bremner (1966) extraction. The narrow range of $\mathrm{C} / \mathrm{N}$ values is remarkable within both the oxidized and unoxidized groups of samples, despite the large range in percent $\mathrm{C}_{\text {org }}$ values for the latter $(0.5 \%-1.6 \%$; Fig. 2). The correlation between $\mathrm{C}_{\text {org }}$ and $\mathrm{N}_{\text {tot }}$ in oxidized samples is good $\left(\mathrm{R}^{2}=0.75\right.$, excluding sample 5007; see below), and all N seems to be related to organic C alone (negligible y-axis intercept). Sample 5007, the "oxidized" sample from interval 11 , deviates in a number of aspects, but especially for the C/N. It appears that sample 5007 is a mixture of oxidized and unoxidized material which corresponds with the sample location/core description (Fig. 1).

The excellent correlation between $\mathrm{C}_{\text {org }}$ and $\mathrm{N}_{\text {tot }}$ in unoxidized samples $\left(\mathrm{R}^{2}=0.95\right)$, with a y-axis cut off of $0.024 \%$, suggests that some of the $\mathrm{N}$ in unoxidized samples is unrelated to organic carbon. Comparing the data in the present study with those in De Lange (1992a), it appears that similar results have been obtained (Table 3). Systematic and thus far unaccounted-for differences occur for the same samples analyzed by Kjeldahl and CNS analyzer techniques. Using calibration lines for oxic and unoxic samples analyzed by the two differ- 
Table 1. Details of sample code, lithologic unit, and results from $\mathrm{C}$ (organic) and $\mathrm{N}$ (total) analyses.

\begin{tabular}{|c|c|c|c|c|c|c|c|c|c|c|c|}
\hline @ & Sample code & ODP code & $\begin{array}{l}\text { Depth } \\
\text { (mbsf) }\end{array}$ & $\begin{array}{l}\text { Lithologic } \\
\text { unit }\end{array}$ & $\begin{array}{l}\mathrm{C}_{\text {org }} \\
(\%)\end{array}$ & $\begin{array}{l}\mathrm{N}_{\text {tot }} \\
(\%)\end{array}$ & $\begin{array}{l}\mathrm{C} / \mathrm{N} \\
(\mathrm{g} / \mathrm{g})\end{array}$ & $\begin{array}{l}{ }^{15} \mathrm{~N} \\
(\% \mathrm{o})\end{array}$ & $\begin{array}{l}{ }^{13} \mathrm{C} \\
(\% \mathrm{o})\end{array}$ & $\begin{array}{c}\mathrm{C} / \mathrm{N} \\
(\mathrm{M} / \mathrm{M})\end{array}$ & $\begin{array}{l}\mathrm{CaCO}_{3} \\
(\%)(\#)\end{array}$ \\
\hline 1 & 5001 & GERT/950A/11H/1/118-125 & 95.58 & Un-ox & 0.52 & 0.057 & 9.1 & 4.7 & -20.2 & 10.7 & 51.9 \\
\hline 2 & $\begin{array}{l}5018 \\
5009 \\
5037\end{array}$ & $\begin{array}{l}\text { COW/951A/7H/6/71-77 } \\
\text { COW/951A/7H/6/88-93 } \\
\text { COW/951A/7H/6/103-112 }\end{array}$ & $\begin{array}{l}60.51 \\
60.68 \\
60.83\end{array}$ & $\begin{array}{l}\text { Ox } \\
\text { Un-ox } \\
\text { Un-ox }\end{array}$ & $\begin{array}{l}0.16 \\
0.70 \\
0.69\end{array}$ & $\begin{array}{l}0.038 \\
0.079 \\
0.079\end{array}$ & $\begin{array}{l}4.3 \\
8.8 \\
8.8\end{array}$ & $\begin{array}{l}(5.2) \\
5.5 \\
5.5\end{array}$ & $\begin{array}{l}-22.1 \\
-20.6 \\
-20.3\end{array}$ & $\begin{array}{r}5.0 \\
10.3 \\
10.3\end{array}$ & $\begin{array}{l}46.8 \\
49.1 \\
49.1\end{array}$ \\
\hline 3 & $\begin{array}{l}5039 \\
5028 \\
5027\end{array}$ & $\begin{array}{l}\text { COW/951A/11H/4/14-20 } \\
\text { COW/951A/11H/4/37-46 } \\
\text { COW/951A/11H/4/76-85 }\end{array}$ & $\begin{array}{l}94.94 \\
95.17 \\
95.56\end{array}$ & $\begin{array}{l}\text { Ox } \\
\text { Un-ox } \\
\text { Un-ox }\end{array}$ & $\begin{array}{l}0.16 \\
0.69 \\
0.68\end{array}$ & $\begin{array}{l}0.043 \\
0.078 \\
0.075\end{array}$ & $\begin{array}{l}3.8 \\
8.8 \\
9.1\end{array}$ & $\begin{array}{l}6.5 \\
5.4 \\
5.3\end{array}$ & $\begin{array}{l}-21.3 \\
-20.3 \\
-20.1\end{array}$ & $\begin{array}{r}4.4 \\
10.3 \\
10.6\end{array}$ & $\begin{array}{l}44.3 \\
45.9 \\
46.2\end{array}$ \\
\hline 4 & $\begin{array}{l}5012 \\
5040 \\
5035\end{array}$ & $\begin{array}{l}\text { COW/951A/15X/3/7-15 } \\
\text { COW/951A/15X/3/46-54 } \\
\text { COW/951A/15X/3/69-76 }\end{array}$ & $\begin{array}{l}128.07 \\
128.46 \\
128.69\end{array}$ & $\begin{array}{l}\text { Ox } \\
\text { Un-ox } \\
\text { Un-ox }\end{array}$ & $\begin{array}{l}0.26 \\
1.32 \\
1.29\end{array}$ & $\begin{array}{l}0.054 \\
0.117 \\
0.116\end{array}$ & $\begin{array}{l}4.8 \\
1.2 \\
1.1\end{array}$ & $\begin{array}{l}5.9 \\
4.5 \\
4.4\end{array}$ & $\begin{array}{l}-19.6 \\
-19.3 \\
-19.3\end{array}$ & $\begin{array}{r}5.6 \\
13.1 \\
13.0\end{array}$ & $\begin{array}{l}0.4 \\
8.5 \\
8.9\end{array}$ \\
\hline 5 & $\begin{array}{l}5036 \\
5041 \\
5023 \\
5026\end{array}$ & $\begin{array}{l}\text { COW/951A/19X/2/4-9 } \\
\text { COW/951A/19X/2/22-32 } \\
\text { COW/951A/19X/2/44-53 } \\
\text { COW/951A/19X/2/63-72 }\end{array}$ & $\begin{array}{l}161.64 \\
161.82 \\
162.04 \\
162.23\end{array}$ & $\begin{array}{l}\text { Ox } \\
\text { Un-ox } \\
\text { Un-ox } \\
\text { Un-ox }\end{array}$ & $\begin{array}{l}0.23 \\
1.47 \\
1.46 \\
1.44\end{array}$ & $\begin{array}{l}0.060 \\
0.131 \\
0.138 \\
0.131\end{array}$ & $\begin{array}{r}3.9 \\
11.2 \\
10.6 \\
11.0\end{array}$ & $\begin{array}{l}7.2 \\
4.4 \\
4.7 \\
4.7\end{array}$ & $\begin{array}{l}-21.2 \\
-19.9 \\
-19.8 \\
-19.7\end{array}$ & $\begin{array}{r}4.5 \\
13.0 \\
12.3 \\
12.8\end{array}$ & $\begin{array}{l}23.4 \\
36.6 \\
36.7 \\
36.7\end{array}$ \\
\hline 6 & $\begin{array}{l}5031 \\
5021 \\
5029 \\
5034\end{array}$ & $\begin{array}{l}\text { COW/951A/25X/3/73-79 } \\
\text { COW/951A/25X/3/96-104 } \\
\text { COW/951A/25X/4/42-50 } \\
\text { COW/951A/25X/4/108-117 }\end{array}$ & $\begin{array}{l}221.73 \\
221.96 \\
222.92 \\
223.58\end{array}$ & $\begin{array}{l}\text { Ox } \\
\text { Un-ox } \\
\text { Un-ox } \\
\text { Un-ox }\end{array}$ & $\begin{array}{l}0.26 \\
1.25 \\
1.27 \\
1.27\end{array}$ & $\begin{array}{l}0.074 \\
0.130 \\
0.130 \\
0.129\end{array}$ & $\begin{array}{l}3.6 \\
9.6 \\
9.8 \\
9.9\end{array}$ & $\begin{array}{l}7.8 \\
5.1 \\
5.2 \\
5.0\end{array}$ & $\begin{array}{l}-21.4 \\
-19.7 \\
-19.6 \\
-19.7\end{array}$ & $\begin{array}{r}4.2 \\
11.2 \\
11.4 \\
11.5\end{array}$ & $\begin{array}{r}2.0 \\
19.3 \\
19.6 \\
19.3\end{array}$ \\
\hline 7 & $\begin{array}{l}5010 \\
5024 \\
5017\end{array}$ & $\begin{array}{l}\text { COW/951B/3X/4/79-84 } \\
\text { COW/951B/3X/4/93-101 } \\
\text { COW/951B/3X/4/107-117 }\end{array}$ & $\begin{array}{l}279.59 \\
279.73 \\
279.87\end{array}$ & $\begin{array}{l}\text { Ox } \\
\text { Un-ox } \\
\text { Un-ox }\end{array}$ & $\begin{array}{l}0.18 \\
1.41 \\
1.34\end{array}$ & $\begin{array}{l}0.053 \\
0.125 \\
0.121\end{array}$ & $\begin{array}{r}3.4 \\
11.3 \\
11.0\end{array}$ & $\begin{array}{l}(8.2) \\
8.0 \\
7.8\end{array}$ & $\begin{array}{l}-22.7 \\
-20.8 \\
-20.9\end{array}$ & $\begin{array}{r}4.0 \\
13.2 \\
13.0\end{array}$ & $\begin{array}{r}1.4 \\
19.2 \\
18.2\end{array}$ \\
\hline 8 & $\begin{array}{l}5019 \\
5004 \\
5011 \\
5030\end{array}$ & $\begin{array}{l}\mathrm{COW} / 952 \mathrm{~A} / 5 \mathrm{H} / 3 / 99-105 \\
\mathrm{COW} / 952 \mathrm{~A} / 5 \mathrm{H} / 3 / 131-140 \\
\mathrm{COW} / 952 \mathrm{~A} / 5 \mathrm{H} / 4 / 15-25 \\
\mathrm{COW} / 952 \mathrm{~A} / 5 \mathrm{H} / 4 / 42-52\end{array}$ & $\begin{array}{l}42.29 \\
42.61 \\
42.95 \\
43.22\end{array}$ & $\begin{array}{l}\text { Ox } \\
\text { Un-ox } \\
\text { Un-ox } \\
\text { Un-ox }\end{array}$ & $\begin{array}{l}0.12 \\
0.81 \\
0.79 \\
0.83\end{array}$ & $\begin{array}{l}0.033 \\
0.089 \\
0.082 \\
0.088\end{array}$ & $\begin{array}{l}3.5 \\
9.2 \\
9.6 \\
9.4\end{array}$ & $\begin{array}{l}5.7 \\
5.4 \\
5.2 \\
5.5\end{array}$ & $\begin{array}{l}-22.0 \\
-20.2 \\
-20.3 \\
-20.1\end{array}$ & $\begin{array}{r}4.1 \\
10.7 \\
11.3 \\
11.0\end{array}$ & $\begin{array}{l}42.5 \\
46.9 \\
47.8 \\
47.5\end{array}$ \\
\hline 9 & $\begin{array}{l}5016 \\
5038 \\
5032 \\
5002\end{array}$ & $\begin{array}{l}\text { COW/952A/9H/5/50-57 } \\
\text { COW/952A/9H/5/94-104 } \\
\text { COW/952A/9H/5/125-135 } \\
\text { COW/952A/9H/6/10-20 }\end{array}$ & $\begin{array}{l}82.8 \\
83.24 \\
83.55 \\
83.9\end{array}$ & $\begin{array}{l}\text { Ox } \\
\text { Un-ox } \\
\text { Un-ox } \\
\text { Un-ox }\end{array}$ & $\begin{array}{l}0.14 \\
0.73 \\
0.78 \\
0.69\end{array}$ & $\begin{array}{l}0.039 \\
0.082 \\
0.085 \\
0.074\end{array}$ & $\begin{array}{l}3.6 \\
8.9 \\
9.2 \\
9.3\end{array}$ & $\begin{array}{l}(4.8) \\
5.1 \\
5.3 \\
5.7\end{array}$ & $\begin{array}{l}-22.3 \\
-20.6 \\
-20.5 \\
-20.6\end{array}$ & $\begin{array}{r}4.1 \\
10.4 \\
10.7 \\
10.9\end{array}$ & $\begin{array}{l}39.8 \\
44.1 \\
45.9 \\
52.2\end{array}$ \\
\hline 10 & $\begin{array}{l}5044 \\
5003 \\
5025 \\
5043\end{array}$ & $\begin{array}{l}\text { COW/952A/15H/1/6-14 } \\
\text { COW/952A/15H/1/64-72 } \\
\text { COW/952A/15H/2/59-67 } \\
\text { COW/952A/15H/3/18-26 }\end{array}$ & $\begin{array}{l}133.36 \\
133.94 \\
135.39 \\
136.48\end{array}$ & $\begin{array}{l}\text { Ox } \\
\text { Un-ox } \\
\text { Un-ox } \\
\text { Un-ox }\end{array}$ & $\begin{array}{l}0.25 \\
1.66 \\
1.59 \\
1.61\end{array}$ & $\begin{array}{l}0.069 \\
0.153 \\
0.146 \\
0.140\end{array}$ & $\begin{array}{r}3.7 \\
10.9 \\
10.9 \\
11.5\end{array}$ & $\begin{array}{l}7.0 \\
4.7 \\
4.2 \\
4.0\end{array}$ & $\begin{array}{l}-20.9 \\
-19.5 \\
-19.4 \\
-19.5\end{array}$ & $\begin{array}{r}4.3 \\
12.7 \\
12.7 \\
13.4\end{array}$ & $\begin{array}{r}5.1 \\
29.1 \\
32.0 \\
30.2\end{array}$ \\
\hline 11 & $\begin{array}{l}5007 \\
5008 \\
5005 \\
5006\end{array}$ & $\begin{array}{l}\text { COW/952A/18X/3/101-111 } \\
\text { COW/952A/18X/3/121-131 } \\
\text { COW/952A/18X/4/7-17 } \\
\text { COW/952A/18X/4/55-64 }\end{array}$ & $\begin{array}{r}159.61 \\
159.81 \\
160.17 \\
16.65\end{array}$ & $\begin{array}{l}\text { Ox } \\
\text { Un-ox } \\
\text { Un-ox } \\
\text { Un-ox }\end{array}$ & $\begin{array}{l}0.45 \\
1.64 \\
1.59 \\
1.55\end{array}$ & $\begin{array}{l}0.076 \\
0.153 \\
0.145 \\
0.137\end{array}$ & $\begin{array}{r}5.9 \\
10.8 \\
1.0 \\
11.3\end{array}$ & $\begin{array}{l}(6.3) \\
5.0 \\
4.5 \\
4.8\end{array}$ & $\begin{array}{l}-20.5 \\
-19.9 \\
-19.8 \\
-19.8\end{array}$ & $\begin{array}{r}6.9 \\
12.6 \\
12.8 \\
13.2\end{array}$ & $\begin{array}{l}20.0 \\
31.7 \\
33.0 \\
34.5\end{array}$ \\
\hline 12 & $\begin{array}{l}5015 \\
5013 \\
5014 \\
5022\end{array}$ & $\begin{array}{l}\text { COW/952A/23X/5/46-52 } \\
\text { COW/952A/23X/5/74-84 } \\
\text { COW/952A/23X/5/115-125 } \\
\text { COW/952A/23X/6/31-41 }\end{array}$ & $\begin{array}{l}210.26 \\
210.56 \\
210.95 \\
211.61\end{array}$ & $\begin{array}{l}\text { Ox } \\
\text { Un-ox } \\
\text { Un-ox } \\
\text { Un-ox }\end{array}$ & $\begin{array}{l}0.21 \\
1.16 \\
1.17 \\
1.09\end{array}$ & $\begin{array}{l}0.057 \\
0.113 \\
0.115 \\
0.107\end{array}$ & $\begin{array}{r}3.7 \\
10.3 \\
10.2 \\
10.2\end{array}$ & $\begin{array}{l}(6.5) \\
5.5 \\
5.3 \\
5.3\end{array}$ & $\begin{array}{l}-22.1 \\
-20.0 \\
-20.0 \\
-19.8\end{array}$ & $\begin{array}{r}4.3 \\
12.0 \\
11.9 \\
11.9\end{array}$ & $\begin{array}{l}20.9 \\
32.7 \\
32.4 \\
33.1\end{array}$ \\
\hline 13 & $\begin{array}{l}5020 \\
5042 \\
5033\end{array}$ & $\begin{array}{l}\text { COW/952A/27X/4/44-50 } \\
\text { COW/952A/27X/4/61-71 } \\
\text { COW/952A/27X/4/82-92 }\end{array}$ & $\begin{array}{l}247.34 \\
247.51 \\
247.72\end{array}$ & $\begin{array}{l}\text { Ox } \\
\text { Un-ox } \\
\text { Un-ox }\end{array}$ & $\begin{array}{l}0.25 \\
1.40 \\
1.39\end{array}$ & $\begin{array}{l}0.085 \\
0.148 \\
0.149\end{array}$ & $\begin{array}{l}2.9 \\
9.5 \\
9.3\end{array}$ & $\begin{array}{l}6.7 \\
4.9 \\
4.9\end{array}$ & $\begin{array}{l}-22.3 \\
-19.0 \\
-19.8\end{array}$ & $\begin{array}{r}3.4 \\
11.0 \\
10.9\end{array}$ & $\begin{array}{r}0.8 \\
15.9 \\
16.0\end{array}$ \\
\hline
\end{tabular}

Note: $@=$ Ox/un-ox interval, and $(\#)=$ difference between acidified and unacidified by CNS-analyzer.

ent techniques, the data of De Lange (1992a) have been adapted for this deviation to allow a direct comparison to be made with the present data. The similarity between the two data sets in $\mathrm{C} / \mathrm{N}$ ratios for oxic and unoxic samples, as well as the identical axes cut offs, are remarkable. The $\mathrm{N}_{\mathrm{o}}\left(\mathrm{N}_{\text {tot }}\right.$ axes intercepts) for the unoxidized samples; that is, the $\mathrm{N}$ fraction that seems unrelated to organic carbon cannot be related to the two commonly identified nonorganic N phases, "exchangeable" and "fixed." In these sediments, exchangeable N appears to be largely associated with organic matter (De Lange, 1992a). In addition, the sum of exchangeable and fixed $\mathrm{N}$ for these late Quaternary sediments is at most half of the observed $\mathrm{N}_{\mathrm{o}}$. It seems, therefore, that at least part of the $\mathrm{N}_{\mathrm{o}}$ is related to organic material. At this moment, it is not clear how this contradiction can be accounted for. Possibly, it is caused by the differential decomposition of compounds that differ greatly in reactivity and in the $\mathrm{C} / \mathrm{N}$ ratio. Some evidence for such differential decomposition can be found in the amino acid and macromolecular compositions before and after oxidation for each turbidite (De Lange et al., 1994; Cowie et al., 1995; Prahl et al., 1997; Cowie et al., Chap. 34, this volume; Hoefs et al., Chap. 35, this volume).

If $\mathrm{C} / \mathrm{N}$ ratios are to be compared with that of plankton (Redfield ratio; Table 3 ), the total $\mathrm{N}$ has to be corrected for nonorganic $\mathrm{N}$ con- tributions (i.e., for exchangeable and fixed N). Such correction mainly affects the $\mathrm{C} / \mathrm{N}$ of oxic samples (Table 3 ), but only in a rather modest way. The dramatic shift upon oxidation remains largely present for the organic-rich turbidites.

From the obtained $\mathrm{C} / \mathrm{N}$ ratios of oxidized and unoxidized samples, it is possible to estimate the $\mathrm{C} / \mathrm{N}$ ratio of the organic matter that has been decomposed (see De Lange, 1992a). The resulting ratio of 14.4 is close to that found for decomposed late Quaternary sediments (13.5) but deviates from the marine plankton ratio (6.6). The remaining organic matter has a considerably decreased $\mathrm{C} / \mathrm{N}$ ratio of 4.6. This low ratio would not generally be considered to be "refractory" or terrestrial material. However, often the $\mathrm{C} / \mathrm{N}$ ratio and ${ }^{13} \mathrm{C}_{\text {org }}$ are considered to be useful parameters to establish a terrestrial/marine source for organic matter (e.g.. Stevenson and Cheng, 1972; Fontugne and Calvert, 1992; Müller et al., 1994; see discussion below).

$$
{ }^{13} \mathbf{C}_{\text {org }} \text { and }{ }^{15} \mathbf{N}_{\text {tot }}
$$

Unoxidized organic-rich turbidite samples with relatively high organic $\mathrm{C}$ contents appear to have, on average, a slightly less negative ${ }^{13} \mathrm{C}_{\text {org }}$ and a slightly lower ${ }^{15} \mathrm{~N}_{\text {tot }}$ than the oxidized samples from the same turbidite (Figs. 2, 3). Organic-rich turbidites in the MAP contain- 


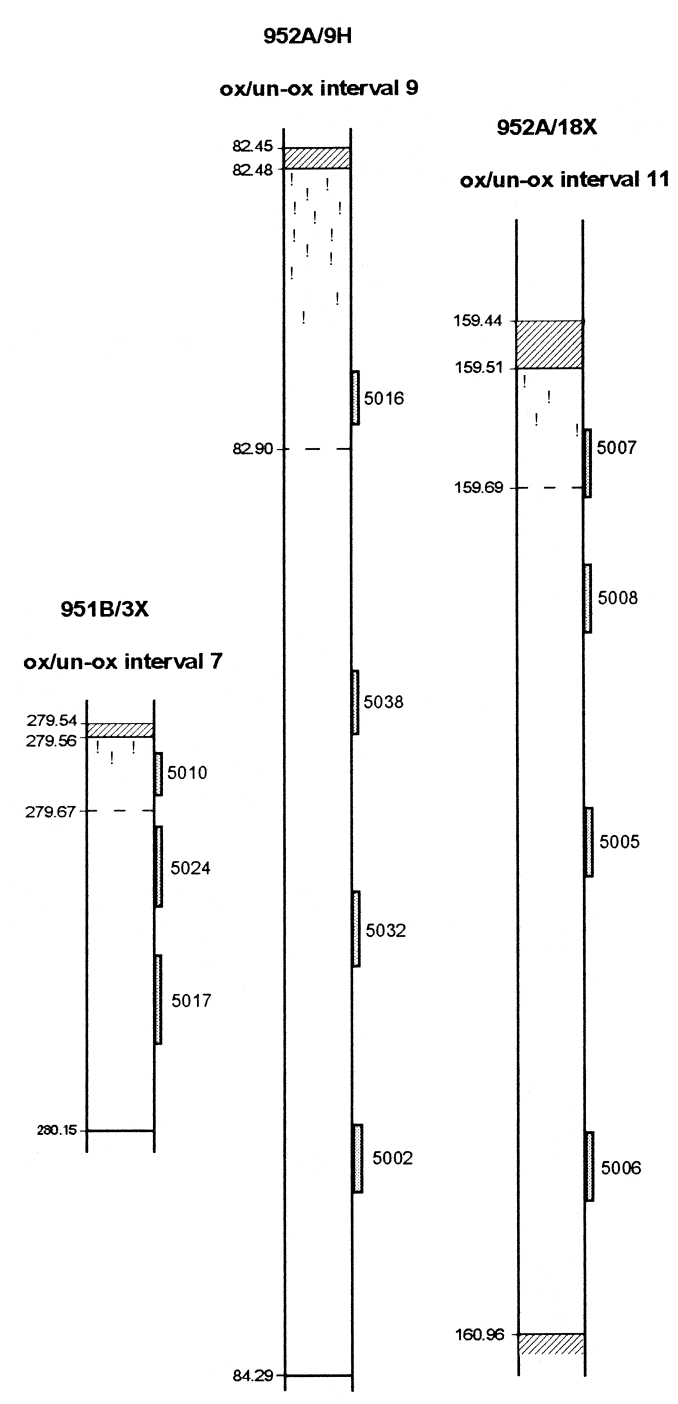

Figure 1. Example of three ox/un-ox intervals that were sampled in three different turbidites. Simplified representation of core description is as follows: pelagic interval $=$ hatched pattern; the sharp color transition between the upper oxidized and the lower unoxidized parts of each turbidite $=$ dashed line; visually observed sediment mixing (bioturbation) = "!" symbol. On the left of each unit, meters below seafloor are indicated; the sampling interval and sample code (see Table 1) are given on the right. The depositional ages of the intervals 7, 9, and 11 are 2.4, 4.5, and $14 \mathrm{Ma}$, respectively (Weaver et al., Chap. 38, this volume).

ing $>1 \%$ organic $\mathrm{C}$ have been reported to originate from a more southern source $\left(<20^{\circ} \mathrm{N}\right)$ than those with $<1 \%$ (De Lange et al., 1987; Kuijpers and Weaver, 1985). A more southern source would typically correspond with slightly higher sea-water temperatures (i.e., less negative ${ }^{13} \mathrm{C}_{\text {org }}$; e.g., Rau, 1994). Therefore, slight differences in ${ }^{13} \mathrm{C}_{\mathrm{org}}$, ${ }^{15} \mathrm{~N}_{\text {tot }}$, and $\mathrm{C}_{\text {org }}$ contents between the unoxidized samples of different turbidites may be related largely to the environment of initial formation of the organic matter. The ${ }^{13} \mathrm{C}_{\text {org }}$ and ${ }^{15} \mathrm{~N}_{\text {tot }}$ of the unoxidized samples of interval 7 , in particular, deviate from those of the other intervals reported here. Clearly, the environmental or climatic conditions of these sediments during their initial deposition before being transported to the present site in the MAP must have been very different from those in the other reported intervals. Redeposition and subsequent oxidation has resulted in a considerable decrease in ${ }^{13} \mathrm{C}_{\text {org }}$ and an increase in the ${ }^{15} \mathrm{~N}_{\text {tot }}$ for the intervals discussed here. However, McArthur et al. (1992) observed a minor shift, or no shift at all, in ${ }^{13} \mathrm{C}_{\text {org }}$ for the A-turbidite. This
Table 2. Percent decrease in $\mathrm{C}_{\text {org }}$ and $\mathrm{N}_{\text {tot }}$ relative to initial concentration, and absolute changes in ${ }^{13} \mathrm{C},{ }^{15} \mathrm{~N}$, and carbonate content.

\begin{tabular}{rcccccc}
\hline \multirow{2}{*}{$@$} & \multirow{2}{*}{$\begin{array}{c}\mathrm{C}_{\mathrm{org}} \\
\text { (rel.\%) }\end{array}$} & \multirow{2}{*}{$\begin{array}{c}\mathrm{N}_{\text {tot }} \\
\text { (rel\%) }\end{array}$} & $\begin{array}{c}{ }^{13} \mathrm{C}_{\text {org }} \\
\text { (abs.change) }\end{array}$ & $\begin{array}{c}{ }^{15} \mathrm{~N}_{\text {tot }} \\
\text { (abs.change) }\end{array}$ & \multicolumn{2}{c}{$\mathrm{CaCO}_{3}$} \\
\cline { 6 - 7 } & & & & & & \\
2 & 76 & 52 & 1.65 & $(0.3)$ & 2.3 & \\
3 & 77 & 44 & 1.1 & 1.2 & 1.7 & 2.7 \\
4 & 80 & 54 & 0.3 & 1.4 & 8.3 & 5.3 \\
5 & 84 & 55 & 1.4 & 1.6 & 13.2 & 6.2 \\
6 & 79 & 43 & 1.73 & 2.7 & 17.4 & 5.0 \\
7 & 87 & 57 & 1.85 & $(0.3)$ & 16.7 & 6.0 \\
8 & 86 & 62 & 1.8 & 0.3 & 4.9 & 3.5 \\
9 & 81 & 51 & 1.73 & $(0.7)$ & 7.6 & 3.0 \\
10 & 84 & 53 & 1.43 & 2.7 & 25.3 & 6.9 \\
11 & 72 & 47 & 0.67 & $(1.5)$ & 13.1 & 5.7 \\
12 & 81 & 49 & 2.17 & $(1.1)$ & 11.9 & 4.7 \\
13 & 82 & 42 & 2.45 & 1.8 & 15.1 & 5.8 \\
Avg. & 74 & 46 & 1.39 & 1.3 & 11.3 & 4.8 \\
\hline
\end{tabular}

Note: $(\#)=$ calculated diagenetic decrease in $\% \mathrm{CaCO}_{3}$, assuming $0.2 \% \mathrm{C}_{\text {org }}$ per $1 \%$ $\mathrm{CaCO}_{3}$.

is probably related to the contact time with oxygen that has been relatively brief for the recent A-turbidite compared to the turbidites in this study and other studies ( $0.5 \mathrm{kyr}$ vs. several thousand years; McArthur et al., 1992; Prahl et al., 1989; De Lange et al., 1994; Cowie et al., 1995; Prahl et al., 1997). Such a decrease in ${ }^{13} \mathrm{C}_{\mathrm{org}}$, combined with the relative abundance of $n$-alkanes, has been interpreted to represent preferential degradation of marine organic compounds over that of terrestrial compounds (Prahl and Muehlhausen, 1989; De Lange et al., 1994; Prahl et al., 1997). Recent reports have shown that a range of ${ }^{13} \mathrm{C}_{\text {org }}$ occurs for different compounds within the marine organic pool (e.g., Jasper and Hayes, 1990, 1994). Low lignin phenol contents and organic geochemical results from pyrolysis gas chromatography-mass spectrometry seem to suggest that most of the organic matter is marine (Cowie et al., 1995; Hoefs et al., Chap. 35, this volume). Therefore, an alternative explanation could be the differential degradation of certain more reactive marine compounds having, on average, a relatively high $\mathrm{C} / \mathrm{N}$ ratio and a low ${ }^{13} \mathrm{C}_{\text {org. }}$. This, however, does not resolve the " $n$-alkane" link to a substantial terrestrial organic source. Detailed organic geochemical studies are needed to reveal the contradiction between enhanced preservation of terrestrial relative to marine organic matter, and the differential degradation of different marine compounds.

\section{Percent $\mathrm{CaCO}_{3}$}

Oxic decomposition of organic matter leads to the dissolution of carbonate (e.g., Emerson and Archer, 1990). During the downwardmoving oxidation in the upper parts of organic-rich turbidites of the MAP, similar diagenetic carbonate dissolution must occur (Thomson et al., 1993). The F-turbidite degradation of $0.8 \%$ organic carbon is accompanied by a $4 \%$ decrease in carbonate content. This ratio agrees well with the overall equation for this reaction, assuming "Redfield" organic matter:

$$
\begin{gathered}
138 \mathrm{O}_{2}+\mathrm{C}_{106} \mathrm{H}_{263} \mathrm{O}_{110} \mathrm{~N}_{16} \mathrm{P}+18 \mathrm{HCO}_{3}{ }^{-} \rightarrow \\
124 \mathrm{CO}_{2}+16 \mathrm{NO}_{3}{ }^{-}+\mathrm{HPO}_{4}{ }^{2-}+140 \mathrm{H}_{2} \mathrm{O}
\end{gathered}
$$

and

$$
\mathrm{CO}_{2}+\mathrm{H}_{2} \mathrm{O}+\mathrm{CaCO}_{3} \rightarrow \mathrm{Ca}^{2+}+2 \mathrm{HCO}_{3}^{-}
$$

However, the F-turbidite also contains almost $1 \%$ sulfur (mostly as pyrite; De Lange et al., 1987), which should upon oxidation, contribute considerably to such carbonate dissolution. Apparently, the total effect of the oxidation of organic $\mathrm{C}$, reduced sulfur, and, possibly, ammonium on carbonate dissolution is equivalent to $1 \%$ carbonate per $0.2 \%$ organic $\mathrm{C}$, including the contribution of reduced $\mathrm{S}$.

Considerably more carbonate dissolution seems to have occurred in some intervals (Table 2). On average, the relative decrease in per- 

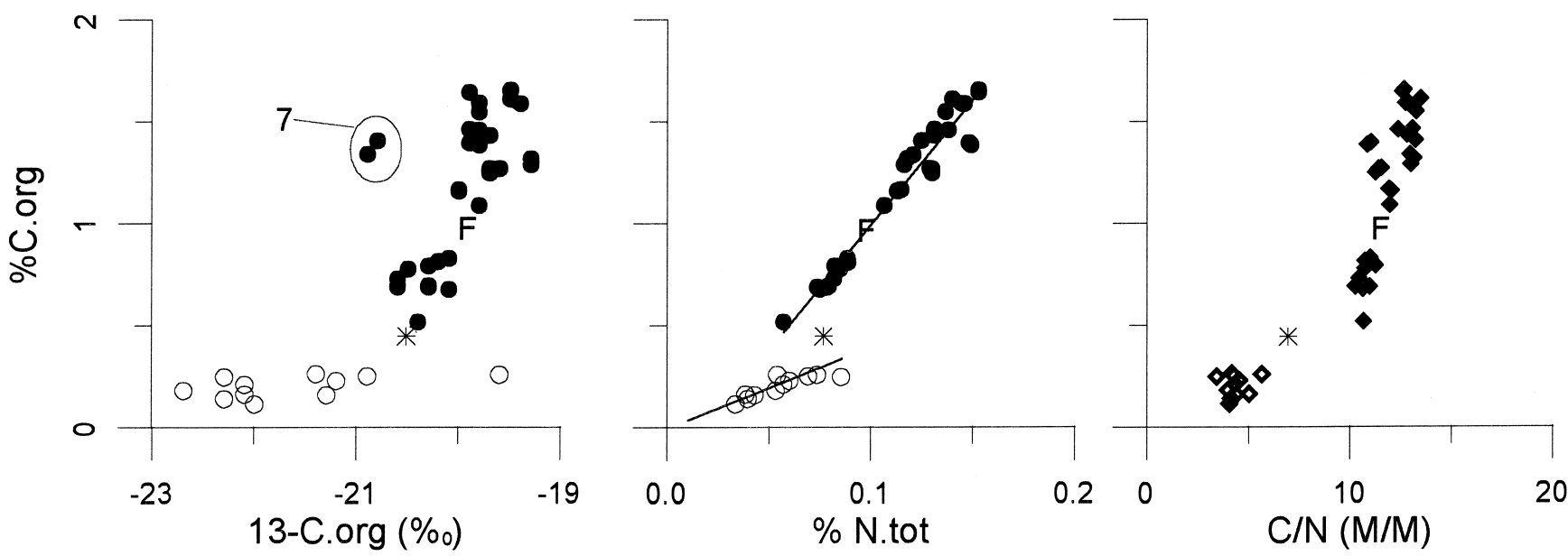

$$
\begin{array}{ll}
\text { ox: } & y=3.9 x-0.003 \\
\text { un-ox: } y=12.3 x-0.2
\end{array}
$$$$
\mathrm{R} 2=0.75(\mathrm{C} / \mathrm{N})=3.9(\mathrm{~g} / \mathrm{g}) \text { or } 4.6(\mathrm{M} / \mathrm{M})
$$$$
\mathrm{R} 2=0.95(\mathrm{C} / \mathrm{N})=12.4(\mathrm{~g} / \mathrm{g}) \text { or } 14.5(\mathrm{M} / \mathrm{M})
$$

Figure 2. Plots of percent organic $\mathrm{C}$ vs. (from left to right) organic ${ }^{13} \mathrm{C}$, percent total $\mathrm{N}$, and molar $\mathrm{C} / \mathrm{N}$ ratio. The deviating unoxidized samples of interval 7 have been marked (see text). Open symbols $=$ oxidized samples, solid symbols $=$ unoxidized samples. $\mathrm{F}=$ unoxidized sample from F-turbidite. $*=$ sample containing oxidized and unoxidized material (see text).

Table 3. C/N correlations of Neogene (this study) and late Quaternary sediments in organic-rich turbidites from the Madeira Abyssal Plain.

\begin{tabular}{llllcc}
\hline & \multicolumn{2}{c}{ Oxidized samples } & & \multicolumn{2}{c}{ Unoxidized samples } \\
\cline { 2 - 3 } \cline { 5 - 6 } & $\mathrm{a}$ & $\mathrm{b}$ & & $\mathrm{a}$ & $\mathrm{b}$ \\
\hline $\mathrm{N}_{\mathrm{o}}(@)$ & 0.0015 & 0.0010 & & 0.025 & 0.023 \\
$(\mathrm{C} / \mathrm{N})(\#)$ & 6.2 & $4.6 \pm 1$ & & 14.4 & 14.5 \\
$(\mathrm{C} / \mathrm{N})(\$)$ & 9.1 & & & 14.0 & \\
\hline
\end{tabular}

Notes: $\mathrm{a}=$ De Lange, 1992a $(\mathrm{n}=127) ; \mathrm{b}=$ this study $(\mathrm{n}=44) ;(@)=$ cut-off at $\mathrm{N}_{\text {tot }}$ axes; $(\#)=\left(\mathrm{C}_{\mathrm{org}} / \mathrm{N}_{\text {tot }}\right)$ in $\mathrm{M} / \mathrm{M} ;(\$)=\left(\mathrm{C}_{\mathrm{org}} / \mathrm{N}_{\text {org }}\right)$ in $\mathrm{M} / \mathrm{M}$. Redfield $(\mathrm{C} / \mathrm{N})$ in $\mathrm{M} / \mathrm{M}=6.6$. Data of De Lange have been corrected for systematic differences between Kjeldahl and CNS analyzer (see text).

cent carbonate seems to correlate nicely with the degree of bioturbative mixing in the samples, as judged from core description and color slides (e.g., compare intervals 7 and 9 in Fig.1; Table 2). Furthermore, oxidized samples, which demonstrate carbonate dissolution in addition to that by diagenesis, have a lower $\mathrm{Ba}^{*}$ content than the unoxidized samples from the same turbidite (Table 4). Most of the Ba is present as barite; consequently, oxidation should not affect the $\mathrm{Ba}^{*}$ concentration. In fact, the oxidation of reduced sulfur might even lead to slightly enhanced concentrations of barite in the sediment. The decrease in $\mathrm{Ba}^{*}$ concentration, observed only in oxidized samples that have an additional decrease in carbonate content, could point to a contribution of pelagic sediment low in $\mathrm{Ba}^{*}$.

Being close to the carbonate compensation depth (CCD), sediments deposited in the MAP will be affected by small variations in CCD (Weaver et al., Chap. 38, this volume). If located below the $\mathrm{CCD}$, bioturbation would lead to the extended exposure of turbidite top sediments to corrosive seawater. Hence, this would lead to enhanced dissolution of carbonate and, by admixing with some pelagic sediment low in $\mathrm{Ba}^{*}$, would lead to a concomitant decrease in $\mathrm{Ba}^{*}$.

\section{Major and Minor Elements}

As large carbonate variations occur, particularly between the oxidized and unoxidized samples, it is necessary to "normalize" the major and minor element concentrations. A convenient way to do this is to multiply the element/Al ratio by the average Al content of all samples (Table 4). Most major and minor elements appear to be unaffect- ed by the oxidation phenomenon (Table 4). There are, however, a few remarks to be made. Reduced $\mathrm{Fe}$ is only part of the total $\mathrm{Fe}$ pool and should, upon oxidation, remain at nearly the same site as a Feoxihydroxide. Reduced S, however, will diffuse away from the site of oxidation as pore-water sulfate. Consequently, large decreases in total $\mathrm{S}$ content are observed upon oxidation. Although most of the remaining $\mathrm{S}$ in the oxidized samples is related to pore-water sulfate, some of it is related to barite. The high $\mathrm{S}$ content in the oxidized sample of interval 3 (sample 5012) is remarkable and cannot be explained by enhanced pore-water or barite content. The low S content of sample 5007 (interval 11) seems in conflict with the statement made earlier in this paper, namely that this sample contains some unoxidized organic material (see Thomson et al., Chap. 32, this volume). This might, however, be explained by the differential oxidation of reduced S relative to organic matter, which may lead to an "S-oxidation front" slightly preceding the "organic-matter oxidation front." There is no satisfactory explanation for the relatively enhanced level of S in sample 5012. The concentrations of phosphorus seem rather high. However, the $\mathrm{P}$ contents in late Quaternary organic-rich turbidite sediments from the MAP appeared to consist for $80 \%$ of "inherited" apatite-P and only for a small fraction of organic P (De Lange, 1992b). The minor decrease in total $\mathrm{P}$ upon oxidation, therefore, does not indicate an enhanced preservation of organic $\mathrm{P}$ relative to organic $\mathrm{C}$ and $\mathrm{N}$, but merely indicates the large pool of nonorganic $\mathrm{P}$.

\section{CONCLUSIONS}

The organic fraction in organic-rich turbidites of the MAP appears to remain virtually unchanged under a large range of suboxic to anoxic conditions and for periods up to $14 \mathrm{Ma}$, whereas dramatic changes occur upon oxidation.

Such post-depositional oxidation of the upper part of initially homogeneous organic-rich turbidites has, on average, resulted in an $80 \%$ decrease in $\% \mathrm{C}_{\text {org }}$ and a $50 \%$ decrease in $\mathrm{N}_{\text {tot }}$. As a consequence, the $\mathrm{C} / \mathrm{N}$ ratio of oxidized samples is substantially lower than that of the unoxidized samples from within the same turbidite (on average 4.6 and 14.4 , respectively), the ${ }^{13} \mathrm{C}_{\text {org }}$ is $1.5 \%$ o more negative, and the ${ }^{15} \mathrm{~N}_{\text {tot }}$ is $1.3 \%$ more positive than that of the unoxidized samples.

Selective preservation of terrestrial over marine organic matter may explain the observed changes upon oxidation; however, differ- 

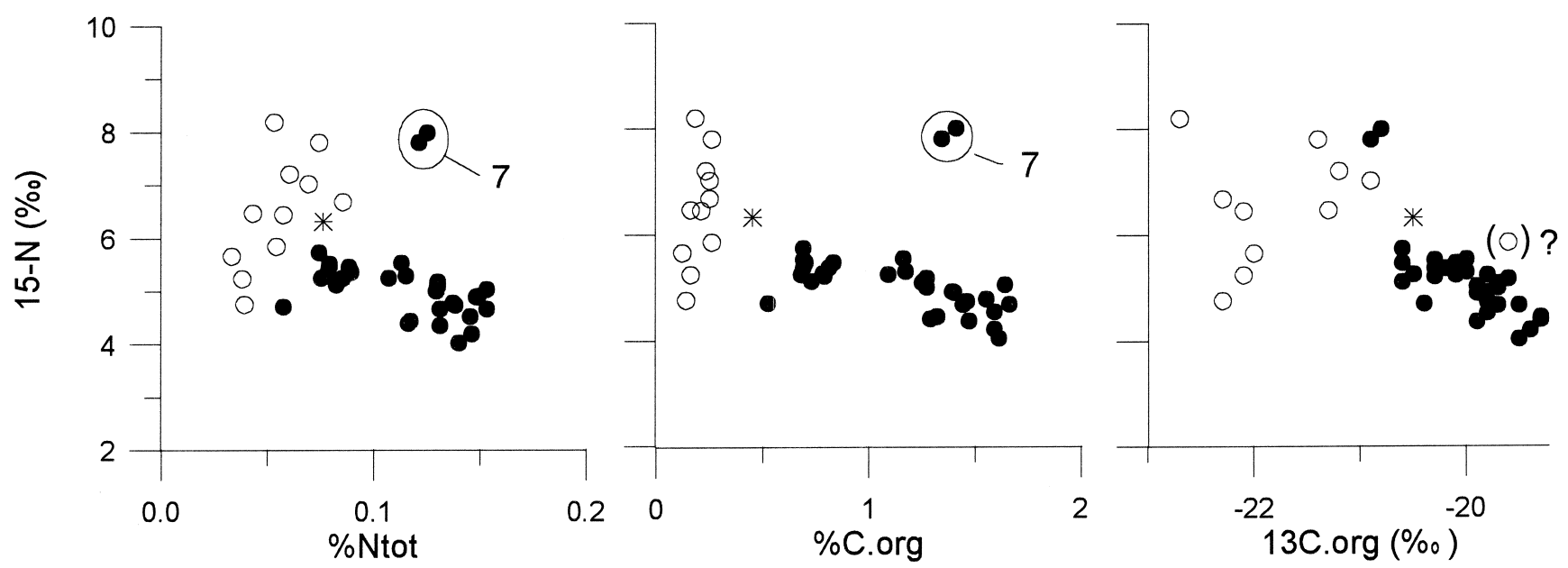

Figure 3. Plots of ${ }^{15} \mathrm{~N}_{\text {tot }}$ vs. (from left) percent total N, percent organic C, and organic ${ }^{13} \mathrm{C}$. (Prahl et al., 1997; De Lange, unpubl. data). For symbols, see Figure 2.

ential decomposition of distinct marine compounds is an alternative explanation. Successive detailed organic geochemical analysis is required to resolve this vital contradiction.

The oxidation of organic matter and reduced sulfur has resulted in the stoichiometric dissolution of some carbonate. An additional decrease in carbonate content is thought to be related to a more shallow $\mathrm{CCD}$, possibly in combination with some bioturbation.

\section{ACKNOWLEDGMENTS}

The Shipboard Scientific Party is acknowledged for taking care of accurate sampling, as is I. Nijenhuis for rapidly transporting the "frozen" samples. H. de Waard, G. Nobbe, A. van Dijk, D. van der Meent, R. Alink, J. Middelburg, and J. Nieuwenhuize are thanked for their analytical assistance. J. Thomson and D. Burdige are acknowledged for their constructive review. This work was supported by GOA/NWO grant no. 750.195.16. This is NSG paper no. 96.1201 .

\section{REFERENCES}

Canfield, D.E., 1989. Sulfate reduction and oxic respiration in marine sediments: implications for organic carbon preservation in euxinic environments. Deep-Sea Res. Part A, 36:121-138.

Colley, S., and Thomson, J., 1985. Recurrent uranium relocations in distal turbidites emplaced in pelagic conditions. Geochim. Cosmochim. Acta, 49:2339-2348.

Colley, S., Thomson, J., Wilson, T.R.S., and Higgs, N.C., 1984. Post-depositional migration of elements during diagenesis in brown clay and turbidite sequences in the North East Atlantic. Geochim. Cosmochim. Acta, 48:1223-1235.

Cowie, G.L., Hedges, J.I., Prahl, F.G., and De Lange, G.J., 1995. Elemental and major biochemical changes across an oxidation front in a relict turbidite: an oxygen effect. Geochim. Cosmochim. Acta, 59:33-46.

De Lange G.J., 1990. Provenance and diagenetic alteration of turbidites in the Madeira Abyssal Plain, eastern North Atlantic: some geochemical aspects. Mem. Soc. Geol. Ital., 44:35-48.

, 1992a. Distribution of exchangeable, fixed, organic and total nitrogen in interbedded turbiditic/pelagic sediments of the Madeira abyssal plain, eastern North Atlantic. Mar. Geol., 109:95-114.

, 1992b. Distribution of various extracted phosphorus compounds in the interbedded turbiditic/pelagic sediments of the Madeira Abyssal Plain, eastern North Atlantic. Mar. Geol., 109:115-139.

De Lange, G.J., Jarvis, I., and Kuijpers, A., 1987. Geochemical characteristics and provenance of late Quaternary sediments from the Madeira Abyssal Plain, North Atlantic. In Weaver, P.P.E., and Thomson, J. (Eds.),
Geology and Geochemistry of Abyssal Plains. Geol. Soc. Spec. Publ. London, 31:147-165.

De Lange, G.J., van Os, B., Pruysers, P.A., Middelburg, J.J., Castradori, D., van Santvoort, P., Müller, P.J., Eggenkamp, H., and Prahl, F.G., 1994. Possible early diagenetic alteration of palaeo proxies. In Zahn, R., Pedersen, T.F., Kaminski, M.A., and Laneyrie, L. (Eds.), Carbon Cycling in the Glacial Ocean: Constraints on the Ocean's Role in Global Change. NATO ASI Ser., I17:225-258.

Emerson, S., and Archer, D., 1990. Calcium carbonate preservation in the ocean. Philos. Trans. R. Soc. London A, 331:29-40.

Fontugne, M.R., and Calvert, S.E., 1992. Late Pleistocene variability of the carbon isotopic composition of organic matter in the eastern Mediterranean: monitor of changes in carbon sources and atmospheric $\mathrm{CO}_{2}$ levels. Paleoceanography, 7:1-20.

Jarvis, I., and Higgs, N., 1987. Trace-element mobility during early diagenesis in distal turbidites: late Quaternary of the Madeira Abyssal Plain, N Atlantic. In Weaver, P.P.E., and Thomson J. (Eds.), Geology and Geochemistry of Abyssal Plains. Geol. Soc. Spec. Publ. London, 31:179214.

Jasper, J.P., and Hayes, J.M., 1990. A carbon isotope record of $\mathrm{CO}_{2}$ levels during the late Quaternary. Nature, 347:462-464.

1994. Reconstruction of paleoceanic $\mathrm{pCO}_{2}$ levels from carbon isotopic compositions of sedimentary biogenic components. In Zahn, R., Pedersen, T.F., Kaminski, M.A., and Laneyrie, L. (Eds.), Carbon Cycling in the Glacial Ocean: Constraints on the Ocean's Role in Global Change. NATO ASI Ser. C, I17:323-366.

Jumars, P.A., Altenbach, A.V., De Lange, G.J., Emerson, S.R., Hargrave, B.T., Muller, P.J., Prahl, F.G., Reimers, C.E., Steiger, T., and Suess, E., 1988. Transformation of seafloor arriving fluxes into the sedimentary record. In Berger, W.H., Smetaceck, V., and Wefer, G. (Eds.), Productivity of the Ocean: Present and Past: Dahlem Workshop, Life Sci. Res. Rep., 44:291-312.

Keil, R.G., Hu, F.S., Tsamakis, E.C., and Hedges, J.I., 1994. Pollen in marine sediments as an indicator of oxidation of organic matter. Nature, 369:639-641.

Kuijpers, A., and Weaver, P.P.E., 1985. Deep-sea turbidites from the northwest African continental margin. Dtsch. Hydrogr. Z., 38:147-164.

McArthur, J.M., Tyson, R.V., Thomson, J., and Mattey, D., 1992. Early diagenesis of marine organic matter: alteration of the carbon isotopic composition. Mar. Geol., 105:51-61.

Müller, P.J., 1977. C/N ratios in Pacific deep sea sediments: effect of inorganic ammonium and organic nitrogen compounds sorbed by clays. Geochim. Cosmochim. Acta, 41:765-776.

Müller, P.J., Schneider, R., and Ruhland, G., 1994. Late Quaternary PCO variations in the Angola Current: evidence from organic carbon $\delta^{13} \mathrm{C}$ and alkenone temperatures. In Zahn, R., Pedersen, T.F., Kaminski, M.A., and Labeyrie, L. (Eds.), Carbon Cycling in the Glacial Ocean: Constraints on the Ocean's Role in Gobal Change: NATO ASI Ser. C, Heidelberg (Springer-Verlag), I17:343-366. 
Pedersen, T.F., and Calvert, S.E., 1990. Anoxia vs. productivity: what controls the formation of organic-carbon-rich sediments and sedimentary rocks? AAPG Bull., 74:454-466.

Prahl, F.G., De Lange, G.J., Lyle, M., and Sparrow, M.A., 1989. Post-depositional stability of long-chain alkenones under contrasting redox conditions. Nature, 341:434-437.

Prahl, F.G., De Lange, G.J., Scholten, S., and Cowie, G.L., 1997. A case for postdepositional aerobic degradation of terrestrial organic matter in turbidite deposits from the Madeira Abyssal Plain. Org. Geochem., 27:141152.

Prahl, F.G., and Muehlhausen, L.A., 1989. Lipid biomarkers as geochemical tools for paleoceanographic study. In Berger, W.H., Smetacek, V.S., and Wefer, G. (Eds.), Productivity of the Ocean: Present and Past. Dahlem Workshop, Life Sci. Res. Rep., 44:271-289.

Rau, G.H., 1994. Variations in sedimentary organic ${ }^{13} \mathrm{C}$ as a proxy for past changes in ocean and atmospheric $\mathrm{CO}_{2}$ concentrations. In Zahn, R., Pedersen, T.F., Kaminski, M.A., and Labeyrie, L. (Eds.), Carbon Cycling in the Glacial Ocean: Constraints on the Ocean's Role in Gobal Change: NATO ASI Ser. C, Heidelberg (Springer-Verlag), I17: 307-321.

Schmincke, H.-U., Weaver, P.P.E., Firth, J.V., et al., 1995. Proc. ODP, Init. Repts., 157: College Station, TX (Ocean Drilling Program).

Silva, J.A., and Bremner, J.M., 1966. Determination and isotope-ratio analysis of different forms of nitrogen in soils. 5: Fixed ammonium. Soil Sci. Soc. Am. Proc., 30:587-594.

Stevenson, F.J., and Cheng, C.N., 1972. Organic geochemistry of the Argentine Basin sediments: carbon-nitrogen relationships and Quaternary correlations. Geochim. Cosmochim. Acta, 36:653-671.

Thomson, J., Colley, S., Higgs, N.C., Hydes, D.J., Wilson T.R.S., and Sorensen, J., 1987. Geochemical oxidation fronts in NE Atlantic distal turbidites and their effects in the sedimentary record. In Weaver, P.P.E., and Thomson, J. (Eds.), Geology and Geochemistry of Abyssal Plains. Geol. Soc. Spec. Publ. London, 31:167-177.

Thomson, J., Higgs, N.C., Croudace, I.W., Colley, S., and Hydes, D.J., 1993. Redox zonation of elements at an oxic/post-oxic boundary in deep-sea sediments. Geochim. Cosmochim. Acta, 57:579-595.
Thomson, J., Wilson, T.R.S., Culkin, F., and Hydes, D.J., 1984. Non-steady state diagenetic record in eastern equatorial Atlantic sediments. Earth Planet. Sci. Lett. 71:23-30.

Van Os, B., Middelburg, J.J., and De Lange, G.J., 1996. Extensive degradation and fractionation of organic matter during subsurface weathering. Aquat. Geochem., 1:1-10.

Van Os, B.J.H., Visser, H.J., Middelburg, J.J., and De Lange, G.J., 1993. Occurrence of thin, metal-rich layers in deep-sea sediments: a geochemical characterization of copper remobilization. Deep-Sea Res., 40:17131730 .

Van Santvoort, P., De Lange, G.J., Thomson, J., Cussen, H., Wilson, T.R.S., Krom, M.D., and Strohle, K., in press. Active post-depositional oxidation of the most recent sapropel (S1) in sediments of the Eastern Mediterranean. Geochim. Cosmochim. Acta.

Weaver, P.P.E., and Kuijpers, A., 1983. Climatic control of turbidite deposition on the Madeira Abyssal Plain. Nature, 306:360-363.

Weaver, P.P.E., and Rothwell, R.G., 1987. Sedimentation on the Madeira Abyssal Plain over the last 300,000 years. In Weaver, P.P.E., and Thomson, J. (Eds.), Geology and Geochemistry of Abyssal Plains. Geol. Soc. Spec. Publ. London, 31:71-86.

Weaver, P.P.E., Rothwell, R.G., Ebbing, J., Gunn, D., and Hunter, P.M., 1992. Correlation, frequency of emplacement and source directions of megaturbidites on the Madeira Abyssal Plain. Mar. Geol., 109:1-20.

Wilson, T.R.S., Thomson, J., Colley, S., Hydes, D.J., Higgs, N.C., and Sørensen, J., 1985. Early organic diagenesis: the significance of progressive subsurface oxidation fronts in pelagic sediments. Geochim. Cosmochim. Acta., 49:811-822.

Wilson, T.R.S, Thomson, J., Hydes, D.J., Colley, S., Culkin, F., and Sørensen, J., 1986. Oxidation fronts in pelagic sediments: diagenetic formation of metal-rich layers. Science, 232:972-975.

Date of initial receipt: 3 July 1996

Date of acceptance: 17 January 1997

Ms 157SR-143 
Table 4. Major and minor element data.

\begin{tabular}{|c|c|c|c|c|c|c|c|c|c|c|c|c|c|c|c|c|c|c|c|c|c|c|}
\hline @ & Sample code & $\begin{array}{l}\mathrm{Mg}^{2} \\
(\%)\end{array}$ & $\begin{array}{l}\mathrm{K}^{*} \\
(\%)\end{array}$ & $\begin{array}{l}\mathrm{Na}^{*} \\
(\%)\end{array}$ & $\begin{array}{l}\mathrm{Ti}^{*} \\
(\%)\end{array}$ & $\begin{array}{l}\mathrm{Fe}^{*} \\
(\%)\end{array}$ & $\begin{array}{c}\mathrm{S}^{*} \\
(\mathrm{ppm})\end{array}$ & $\begin{array}{c}\mathrm{Mn}^{*} \\
(\mathrm{ppm})\end{array}$ & $\begin{array}{c}\mathrm{Sr}^{*} \\
(\mathrm{ppm})\end{array}$ & $\begin{array}{c}\mathrm{P}^{*} \\
(\mathrm{ppm})\end{array}$ & $\begin{array}{c}\mathrm{Cr}^{*} \\
(\mathrm{ppm})\end{array}$ & $\begin{array}{c}\mathrm{Zn*}^{*} \\
(\mathrm{ppm})\end{array}$ & $\begin{array}{c}\mathrm{Co}^{*} \\
(\mathrm{ppm})\end{array}$ & $\begin{array}{c}\mathrm{Ni}^{*} \\
(\mathrm{ppm})\end{array}$ & $\begin{array}{c}\mathrm{V}^{*} \\
(\mathrm{ppm})\end{array}$ & $\begin{array}{c}\mathrm{Cu}^{*} \\
(\mathrm{ppm})\end{array}$ & $\begin{array}{c}\mathrm{Ba}^{*} \\
(\mathrm{ppm})\end{array}$ & $\begin{array}{c}\mathrm{Be}^{*} \\
(\mathrm{ppm})\end{array}$ & $\begin{array}{c}\mathrm{Li}^{*} \\
(\mathrm{ppm})\end{array}$ & $\begin{array}{c}\mathrm{Zr*}^{*} \\
(\mathrm{ppm})\end{array}$ & $\begin{array}{c}\mathrm{Sc}^{*} \\
(\mathrm{ppm})\end{array}$ & $\begin{array}{c}\mathrm{Y}^{*} \\
(\mathrm{ppm})\end{array}$ \\
\hline 1 & 5001 & 2.29 & 2.47 & 1.38 & 0.448 & 3.43 & 9600 & 774 & 1454 & 829 & 87 & 135 & 13 & 44 & 105 & 40 & 478 & 1.83 & 66 & 113 & 12.3 & 27.4 \\
\hline 2 & $\begin{array}{l}5018 \\
5009 \\
5037\end{array}$ & $\begin{array}{l}2.10 \\
2.05 \\
2.07\end{array}$ & $\begin{array}{l}2.18 \\
2.42 \\
1.74\end{array}$ & $\begin{array}{l}1.22 \\
1.33 \\
1.41\end{array}$ & $\begin{array}{l}0.383 \\
0.390 \\
0.385\end{array}$ & $\begin{array}{l}3.21 \\
3.14 \\
3.14\end{array}$ & $\begin{array}{l}1153 \\
4992 \\
4960\end{array}$ & $\begin{array}{l}546 \\
448 \\
463\end{array}$ & $\begin{array}{l}1173 \\
1305 \\
1296\end{array}$ & $\begin{array}{l}750 \\
777 \\
828\end{array}$ & $\begin{array}{r}100 \\
89 \\
95\end{array}$ & $\begin{array}{l}132 \\
130 \\
122\end{array}$ & $\begin{array}{l}14 \\
14 \\
13\end{array}$ & $\begin{array}{l}50 \\
53 \\
52\end{array}$ & $\begin{array}{l}121 \\
112 \\
109\end{array}$ & $\begin{array}{l}41 \\
45 \\
47\end{array}$ & $\begin{array}{l}592 \\
582 \\
575\end{array}$ & $\begin{array}{l}2.10 \\
1.98 \\
2.05\end{array}$ & $\begin{array}{l}69 \\
70 \\
70\end{array}$ & $\begin{array}{l}108 \\
113 \\
109\end{array}$ & $\begin{array}{l}12.7 \\
12.6 \\
12.6\end{array}$ & $\begin{array}{l}27.0 \\
27.2 \\
27.1\end{array}$ \\
\hline 3 & $\begin{array}{l}5039 \\
5028 \\
5027\end{array}$ & $\begin{array}{l}2.19 \\
2.10 \\
2.12\end{array}$ & $\begin{array}{l}1.86 \\
1.57 \\
1.77\end{array}$ & $\begin{array}{l}0.97 \\
1.07 \\
1.10\end{array}$ & $\begin{array}{l}0.384 \\
0.385 \\
0.394\end{array}$ & $\begin{array}{l}3.15 \\
3.20 \\
3.42\end{array}$ & $\begin{array}{r}1143 \\
7448 \\
10446\end{array}$ & $\begin{array}{l}599 \\
432 \\
460\end{array}$ & $\begin{array}{l}1007 \\
1136 \\
1157\end{array}$ & $\begin{array}{l}808 \\
919 \\
858\end{array}$ & $\begin{array}{l}95 \\
91 \\
94\end{array}$ & $\begin{array}{l}117 \\
114 \\
116\end{array}$ & $\begin{array}{l}11 \\
13 \\
11\end{array}$ & $\begin{array}{l}37 \\
47 \\
43\end{array}$ & $\begin{array}{l}116 \\
108 \\
107\end{array}$ & $\begin{array}{l}42 \\
34 \\
33\end{array}$ & $\begin{array}{l}447 \\
451 \\
450\end{array}$ & $\begin{array}{l}2.02 \\
1.92 \\
1.89\end{array}$ & $\begin{array}{l}68 \\
68 \\
68\end{array}$ & $\begin{array}{l}94 \\
91 \\
94\end{array}$ & $\begin{array}{l}12.7 \\
12.4 \\
12.4\end{array}$ & $\begin{array}{l}24.9 \\
23.7 \\
23.5\end{array}$ \\
\hline 4 & $\begin{array}{l}5012 \\
5040 \\
5035\end{array}$ & $\begin{array}{l}0.82 \\
0.69 \\
0.69\end{array}$ & $\begin{array}{l}1.40 \\
0.84 \\
1.07\end{array}$ & $\begin{array}{l}0.68 \\
0.63 \\
0.63\end{array}$ & $\begin{array}{l}0.368 \\
0.356 \\
0.371\end{array}$ & $\begin{array}{l}3.67 \\
3.12 \\
3.27\end{array}$ & $\begin{array}{l}3862 \\
3469 \\
5122\end{array}$ & $\begin{array}{l}119 \\
188 \\
210\end{array}$ & $\begin{array}{r}74 \\
182 \\
185\end{array}$ & $\begin{array}{l}263 \\
251 \\
252\end{array}$ & $\begin{array}{l}108 \\
105 \\
107\end{array}$ & $\begin{array}{l}48 \\
51 \\
54\end{array}$ & $\begin{array}{l}12 \\
12 \\
16\end{array}$ & $\begin{array}{l}47 \\
42 \\
45\end{array}$ & $\begin{array}{r}104 \\
97 \\
98\end{array}$ & $\begin{array}{l}18 \\
28 \\
28\end{array}$ & $\begin{array}{l}267 \\
271 \\
285\end{array}$ & $\begin{array}{l}1.65 \\
1.55 \\
1.51\end{array}$ & $\begin{array}{l}70 \\
72 \\
71\end{array}$ & $\begin{array}{l}87 \\
83 \\
85\end{array}$ & $\begin{array}{l}12.5 \\
12.3 \\
12.2\end{array}$ & $\begin{array}{l}12.8 \\
15.2 \\
14.1\end{array}$ \\
\hline 5 & $\begin{array}{l}5036 \\
5041 \\
5023 \\
5026\end{array}$ & $\begin{array}{l}1.65 \\
1.47 \\
1.48 \\
1.49\end{array}$ & $\begin{array}{l}1.12 \\
1.44 \\
1.68 \\
1.49\end{array}$ & $\begin{array}{l}0.89 \\
0.90 \\
0.89 \\
0.94\end{array}$ & $\begin{array}{l}0.387 \\
0.387 \\
0.385 \\
0.384\end{array}$ & $\begin{array}{l}3.27 \\
3.18 \\
3.29 \\
3.27\end{array}$ & $\begin{array}{r}548 \\
10037 \\
11500 \\
11627\end{array}$ & $\begin{array}{l}225 \\
224 \\
224 \\
226\end{array}$ & $\begin{array}{l}463 \\
824 \\
838 \\
835\end{array}$ & $\begin{array}{l}620 \\
700 \\
724 \\
721\end{array}$ & $\begin{array}{l}121 \\
129 \\
124 \\
127\end{array}$ & $\begin{array}{l}74 \\
94 \\
95 \\
89\end{array}$ & $\begin{array}{l}10 \\
12 \\
10 \\
11\end{array}$ & $\begin{array}{l}30 \\
53 \\
47 \\
48\end{array}$ & $\begin{array}{l}90 \\
93 \\
90 \\
90\end{array}$ & $\begin{array}{l}22 \\
30 \\
31 \\
29\end{array}$ & $\begin{array}{l}331 \\
411 \\
411 \\
412\end{array}$ & $\begin{array}{l}1.79 \\
1.67 \\
1.64 \\
1.63\end{array}$ & $\begin{array}{l}72 \\
74 \\
76 \\
76\end{array}$ & $\begin{array}{l}97 \\
96 \\
94 \\
94\end{array}$ & $\begin{array}{l}12.9 \\
12.4 \\
12.4 \\
12.3\end{array}$ & $\begin{array}{l}20.2 \\
20.6 \\
19.8 \\
19.9\end{array}$ \\
\hline 6 & $\begin{array}{l}5031 \\
5021 \\
5029 \\
5034\end{array}$ & $\begin{array}{l}1.15 \\
1.07 \\
1.09 \\
1.07\end{array}$ & $\begin{array}{l}1.12 \\
1.32 \\
0.96 \\
1.42\end{array}$ & $\begin{array}{l}0.74 \\
0.70 \\
0.75 \\
0.72\end{array}$ & $\begin{array}{l}0.367 \\
0.353 \\
0.358 \\
0.368\end{array}$ & $\begin{array}{l}3.32 \\
3.11 \\
3.26 \\
3.30\end{array}$ & $\begin{array}{r}866 \\
5625 \\
7510 \\
8275\end{array}$ & $\begin{array}{l}146 \\
200 \\
211 \\
211\end{array}$ & $\begin{array}{l}104 \\
354 \\
371 \\
375\end{array}$ & $\begin{array}{l}399 \\
443 \\
445 \\
441\end{array}$ & $\begin{array}{l}122 \\
117 \\
118 \\
119\end{array}$ & $\begin{array}{l}56 \\
71 \\
71 \\
74\end{array}$ & $\begin{array}{l}12 \\
14 \\
10 \\
11\end{array}$ & $\begin{array}{l}39 \\
53 \\
47 \\
50\end{array}$ & $\begin{array}{l}97 \\
93 \\
94 \\
93\end{array}$ & $\begin{array}{l}24 \\
28 \\
28 \\
28\end{array}$ & $\begin{array}{l}354 \\
394 \\
413 \\
395\end{array}$ & $\begin{array}{l}1.73 \\
1.61 \\
1.58 \\
1.57\end{array}$ & $\begin{array}{l}74 \\
76 \\
77 \\
76\end{array}$ & $\begin{array}{l}81 \\
76 \\
79 \\
83\end{array}$ & $\begin{array}{l}12.8 \\
12.2 \\
12.2 \\
12.2\end{array}$ & $\begin{array}{l}14.2 \\
15.6 \\
15.4 \\
16.3\end{array}$ \\
\hline 7 & $\begin{array}{l}5010 \\
5024 \\
5017\end{array}$ & $\begin{array}{l}2.04 \\
1.94 \\
1.91\end{array}$ & $\begin{array}{l}1.88 \\
1.76 \\
1.84\end{array}$ & $\begin{array}{l}1.15 \\
1.37 \\
1.37\end{array}$ & $\begin{array}{l}0.402 \\
0.372 \\
0.370\end{array}$ & $\begin{array}{l}4.17 \\
3.84 \\
4.36\end{array}$ & $\begin{array}{r}1139 \\
12106 \\
18469\end{array}$ & $\begin{array}{l}698 \\
635 \\
611\end{array}$ & $\begin{array}{l}142 \\
541 \\
539\end{array}$ & $\begin{array}{l}1508 \\
1543 \\
1551\end{array}$ & $\begin{array}{l}144 \\
151 \\
149\end{array}$ & $\begin{array}{r}98 \\
113 \\
128\end{array}$ & $\begin{array}{l}12 \\
15 \\
10\end{array}$ & $\begin{array}{l}45 \\
76 \\
77\end{array}$ & $\begin{array}{l}114 \\
110 \\
109\end{array}$ & $\begin{array}{l}28 \\
36 \\
38\end{array}$ & $\begin{array}{l}334 \\
369 \\
375\end{array}$ & $\begin{array}{l}1.89 \\
1.69 \\
1.66\end{array}$ & $\begin{array}{l}75 \\
80 \\
79\end{array}$ & $\begin{array}{r}123 \\
97 \\
94\end{array}$ & $\begin{array}{l}14.8 \\
12.3 \\
12.1\end{array}$ & $\begin{array}{l}35.3 \\
25.0 \\
23.7\end{array}$ \\
\hline 8 & $\begin{array}{l}5019 \\
5004 \\
5011 \\
5030\end{array}$ & $\begin{array}{l}2.02 \\
2.00 \\
2.03 \\
2.03\end{array}$ & $\begin{array}{l}2.33 \\
2.32 \\
2.27 \\
2.21\end{array}$ & $\begin{array}{l}1.57 \\
1.72 \\
1.73 \\
1.83\end{array}$ & $\begin{array}{l}0.442 \\
0.452 \\
0.457 \\
0.459\end{array}$ & $\begin{array}{l}3.48 \\
3.30 \\
3.35 \\
3.35\end{array}$ & $\begin{array}{l}1237 \\
6093 \\
5862 \\
6380\end{array}$ & $\begin{array}{l}748 \\
604 \\
644 \\
655\end{array}$ & $\begin{array}{l}1040 \\
1275 \\
1297 \\
1305\end{array}$ & $\begin{array}{r}914 \\
967 \\
976 \\
1000\end{array}$ & $\begin{array}{r}93 \\
97 \\
127 \\
97\end{array}$ & $\begin{array}{l}120 \\
131 \\
135 \\
135\end{array}$ & $\begin{array}{l}18 \\
18 \\
14 \\
13\end{array}$ & $\begin{array}{l}51 \\
72 \\
67 \\
56\end{array}$ & $\begin{array}{l}116 \\
117 \\
115 \\
115\end{array}$ & $\begin{array}{l}51 \\
61 \\
60 \\
61\end{array}$ & $\begin{array}{l}726 \\
719 \\
716 \\
718\end{array}$ & $\begin{array}{l}2.04 \\
1.99 \\
1.98 \\
2.00\end{array}$ & $\begin{array}{l}67 \\
68 \\
68 \\
69\end{array}$ & $\begin{array}{l}110 \\
112 \\
122 \\
116\end{array}$ & $\begin{array}{l}13.3 \\
13.2 \\
13.4 \\
13.3\end{array}$ & $\begin{array}{l}30.1 \\
30.6 \\
32.2 \\
30.9\end{array}$ \\
\hline 9 & $\begin{array}{l}5016 \\
5038 \\
5032 \\
5002\end{array}$ & $\begin{array}{l}1.99 \\
2.02 \\
2.00 \\
1.90\end{array}$ & $\begin{array}{l}1.96 \\
1.85 \\
2.06 \\
2.35\end{array}$ & $\begin{array}{l}1.07 \\
1.20 \\
1.10 \\
1.19\end{array}$ & $\begin{array}{l}0.386 \\
0.404 \\
0.400 \\
0.387\end{array}$ & $\begin{array}{l}3.27 \\
3.35 \\
3.39 \\
3.33\end{array}$ & $\begin{array}{r}810 \\
8317 \\
7762 \\
6307\end{array}$ & $\begin{array}{l}805 \\
642 \\
640 \\
815\end{array}$ & $\begin{array}{r}880 \\
1138 \\
1139 \\
1467\end{array}$ & $\begin{array}{l}690 \\
795 \\
757 \\
757\end{array}$ & $\begin{array}{l}89 \\
92 \\
91 \\
89\end{array}$ & $\begin{array}{l}101 \\
119 \\
124 \\
135\end{array}$ & $\begin{array}{l}13 \\
12 \\
11 \\
12\end{array}$ & $\begin{array}{l}36 \\
47 \\
46 \\
49\end{array}$ & $\begin{array}{l}107 \\
107 \\
108 \\
112\end{array}$ & $\begin{array}{l}37 \\
39 \\
40 \\
47\end{array}$ & $\begin{array}{l}494 \\
506 \\
504 \\
534\end{array}$ & $\begin{array}{l}2.02 \\
1.98 \\
2.08 \\
2.00\end{array}$ & $\begin{array}{l}66 \\
68 \\
67 \\
66\end{array}$ & $\begin{array}{l}105 \\
107 \\
106 \\
105\end{array}$ & $\begin{array}{l}12.6 \\
12.7 \\
12.5 \\
12.6\end{array}$ & $\begin{array}{l}25.7 \\
26.3 \\
25.8 \\
27.7\end{array}$ \\
\hline 10 & $\begin{array}{l}5044 \\
5003 \\
5025 \\
5043\end{array}$ & $\begin{array}{l}1.25 \\
1.23 \\
1.30 \\
1.22\end{array}$ & $\begin{array}{l}0.94 \\
1.60 \\
1.66 \\
0.99\end{array}$ & $\begin{array}{l}0.85 \\
0.89 \\
0.93 \\
0.91\end{array}$ & $\begin{array}{l}0.376 \\
0.369 \\
0.376 \\
0.379\end{array}$ & $\begin{array}{l}3.49 \\
3.84 \\
3.53 \\
3.47\end{array}$ & $\begin{array}{r}866 \\
16586 \\
13918 \\
12389\end{array}$ & $\begin{array}{l}167 \\
299 \\
327 \\
296\end{array}$ & $\begin{array}{l}147 \\
625 \\
698 \\
646\end{array}$ & $\begin{array}{l}628 \\
803 \\
852 \\
814\end{array}$ & $\begin{array}{l}125 \\
122 \\
120 \\
122\end{array}$ & $\begin{array}{l}59 \\
82 \\
87 \\
87\end{array}$ & $\begin{array}{l}10 \\
11 \\
11 \\
12\end{array}$ & $\begin{array}{l}31 \\
49 \\
49 \\
48\end{array}$ & $\begin{array}{l}99 \\
95 \\
96 \\
96\end{array}$ & $\begin{array}{l}21 \\
31 \\
33 \\
32\end{array}$ & $\begin{array}{l}411 \\
517 \\
511 \\
491\end{array}$ & $\begin{array}{l}1.77 \\
1.58 \\
1.58 \\
1.56\end{array}$ & $\begin{array}{l}67 \\
71 \\
73 \\
68\end{array}$ & $\begin{array}{l}88 \\
90 \\
90 \\
93\end{array}$ & $\begin{array}{l}13.1 \\
12.2 \\
12.0 \\
12.3\end{array}$ & $\begin{array}{l}18.8 \\
18.6 \\
19.9 \\
19.6\end{array}$ \\
\hline 11 & $\begin{array}{l}5007 \\
5008 \\
5005 \\
5006\end{array}$ & $\begin{array}{l}1.65 \\
1.42 \\
1.44 \\
1.47\end{array}$ & $\begin{array}{l}1.76 \\
1.66 \\
1.67 \\
1.69\end{array}$ & $\begin{array}{l}0.85 \\
0.83 \\
0.86 \\
0.89\end{array}$ & $\begin{array}{l}0.376 \\
0.376 \\
0.382 \\
0.391\end{array}$ & $\begin{array}{l}3.01 \\
3.39 \\
3.21 \\
3.27\end{array}$ & $\begin{array}{r}658 \\
13422 \\
11272 \\
12548\end{array}$ & $\begin{array}{l}210 \\
207 \\
214 \\
226\end{array}$ & $\begin{array}{l}377 \\
685 \\
723 \\
759\end{array}$ & $\begin{array}{l}590 \\
681 \\
685 \\
735\end{array}$ & $\begin{array}{l}130 \\
127 \\
127 \\
124\end{array}$ & $\begin{array}{l}80 \\
84 \\
90 \\
88\end{array}$ & $\begin{array}{l}10 \\
10 \\
11 \\
10\end{array}$ & $\begin{array}{l}33 \\
51 \\
48 \\
47\end{array}$ & $\begin{array}{l}93 \\
91 \\
90 \\
90\end{array}$ & $\begin{array}{l}33 \\
27 \\
28 \\
30\end{array}$ & $\begin{array}{l}345 \\
432 \\
442 \\
433\end{array}$ & $\begin{array}{l}1.77 \\
1.66 \\
1.63 \\
1.62\end{array}$ & $\begin{array}{l}71 \\
75 \\
73 \\
74\end{array}$ & $\begin{array}{r}96 \\
94 \\
96 \\
103\end{array}$ & $\begin{array}{l}12.8 \\
12.4 \\
12.5 \\
12.4\end{array}$ & $\begin{array}{l}19.2 \\
18.6 \\
19.2 \\
20.1\end{array}$ \\
\hline 12 & $\begin{array}{l}5015 \\
5013 \\
5014 \\
5022\end{array}$ & $\begin{array}{l}1.38 \\
1.29 \\
1.29 \\
1.30\end{array}$ & $\begin{array}{l}1.57 \\
1.57 \\
1.58 \\
1.23\end{array}$ & $\begin{array}{l}0.74 \\
0.73 \\
0.75 \\
0.80\end{array}$ & $\begin{array}{l}0.374 \\
0.379 \\
0.373 \\
0.381\end{array}$ & $\begin{array}{l}2.80 \\
3.01 \\
3.20 \\
2.98\end{array}$ & $\begin{array}{r}555 \\
7282 \\
10339 \\
7328\end{array}$ & $\begin{array}{l}414 \\
375 \\
376 \\
409\end{array}$ & $\begin{array}{l}374 \\
644 \\
640 \\
673\end{array}$ & $\begin{array}{l}564 \\
628 \\
623 \\
642\end{array}$ & $\begin{array}{l}120 \\
120 \\
120 \\
120\end{array}$ & $\begin{array}{l}71 \\
83 \\
80 \\
85\end{array}$ & $\begin{array}{r}22 \\
9 \\
10 \\
10\end{array}$ & $\begin{array}{l}45 \\
45 \\
43 \\
45\end{array}$ & $\begin{array}{l}94 \\
88 \\
89 \\
89\end{array}$ & $\begin{array}{l}25 \\
27 \\
26 \\
29\end{array}$ & $\begin{array}{l}254 \\
260 \\
260 \\
279\end{array}$ & $\begin{array}{l}1.71 \\
1.55 \\
1.56 \\
1.56\end{array}$ & $\begin{array}{l}72 \\
75 \\
75 \\
75\end{array}$ & $\begin{array}{l}93 \\
93 \\
93 \\
91\end{array}$ & $\begin{array}{l}11.9 \\
11.6 \\
11.6 \\
11.7\end{array}$ & $\begin{array}{l}20.1 \\
19.4 \\
18.8 \\
19.7\end{array}$ \\
\hline 13 & $\begin{array}{l}5020 \\
5042 \\
5033\end{array}$ & $\begin{array}{l}1.11 \\
1.10 \\
1.11\end{array}$ & $\begin{array}{l}1.29 \\
1.12 \\
1.39\end{array}$ & $\begin{array}{l}0.73 \\
0.72 \\
0.72\end{array}$ & $\begin{array}{l}0.352 \\
0.345 \\
0.344\end{array}$ & $\begin{array}{l}3.38 \\
3.45 \\
3.55\end{array}$ & $\begin{array}{r}300 \\
6611 \\
7586\end{array}$ & $\begin{array}{l}276 \\
328 \\
363\end{array}$ & $\begin{array}{r}88 \\
290 \\
295\end{array}$ & $\begin{array}{l}453 \\
514 \\
510\end{array}$ & $\begin{array}{l}121 \\
120 \\
119\end{array}$ & $\begin{array}{l}67 \\
79 \\
77\end{array}$ & $\begin{array}{l}22 \\
17 \\
17\end{array}$ & $\begin{array}{l}52 \\
61 \\
58\end{array}$ & $\begin{array}{r}100 \\
97 \\
96\end{array}$ & $\begin{array}{l}34 \\
32 \\
32\end{array}$ & $\begin{array}{l}345 \\
362 \\
373\end{array}$ & $\begin{array}{l}1.82 \\
1.68 \\
1.68\end{array}$ & $\begin{array}{l}71 \\
75 \\
74\end{array}$ & $\begin{array}{l}77 \\
73 \\
75\end{array}$ & $\begin{array}{l}13.1 \\
12.8 \\
12.8\end{array}$ & $\begin{array}{l}15.3 \\
15.6 \\
15.8\end{array}$ \\
\hline
\end{tabular}

Note: $(@)=$ oxic/un-oxic interval, and $(*)=$ element/Al ratio has been multiplied with the average $\mathrm{Al}$ content of all samples.

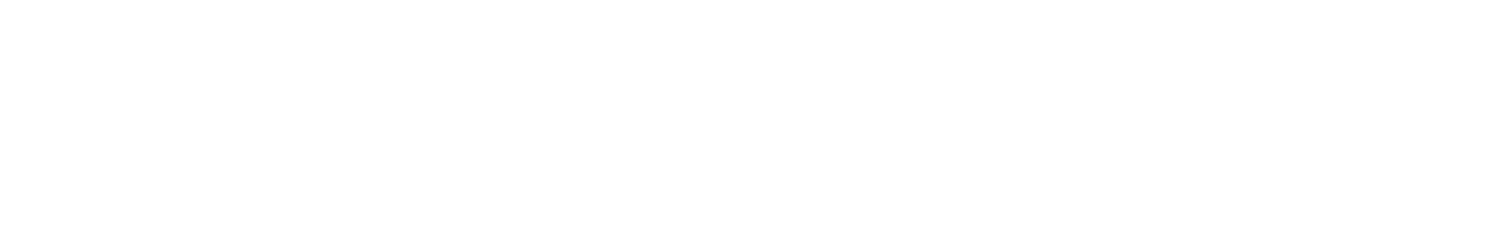

